\title{
ECHOES OF COUNTERCULTURE IN STEFANO BENNI'S HUMOUR
}

\author{
Monica Boria
}

Anglia Polytechnic University, UK

Stefano Benni's first novel, Terra! (1983) - a sci-fi spoof and a satire of contemporary life - set the trend for his subsequent fiction. Blending fantasy, pop culture, literary pastiche and current affairs, Benni's political and social satires have been nationally and internationally successful. Less known yet crucial to the understanding of his fiction as well as to his use of humour are his earlier writings and their engagement with social and political issues. This study aims to show that the roots of Benni's humour, with its coarse language, puns, pastiche and mocking tone, are to be found in the student spirit and political protest of the 1970s. Adopting an interdisciplinary approach which draws on social history as well as structuralist methods of literary analysis, it argues that the subtle rhetorical strategies employed, as well as the strong underlying political intent, militate against the dismissive label of 'popular fiction writer' attached to him by some critics.

Stefano Benni, born in Bologna in I947, started his career in the mid-I970s as a journalist and humorous writer for the far-left daily, Il Manifesto. His first collection of short stories, Bar sport (Mondadori, I976), was a success that paved the way, in the early I980s, for his launch as a novelist by Feltrinelli publishers: his first novel, Terra! (I983) - a sci-fi spoof and biting satire of contemporary society — was a bestseller and set the trend for his successive fiction, which has since achieved national and international success. In a compelling blend of fantasy, pop culture, literary allusions, and current affairs, Benni's parodies and satires of social fads and political establishments have made him a classic of contemporary humorous writing in Italy. The neologism 'benniano' is often used to denote that blend of satirical bite and linguistic invention typical of his style, a style that has grabbed the attention of many young readers but also academics in Italy and abroad. Due to the variety of techniques, genres and nuances of tone that he has used over twenty-five years, and also to the changed cultural and political episteme, his work has been difficult to categorize. His irreverence has allowed him to parody traditionally serious forms and to embed serious discourse in minor or popular genres like science fiction and children's literature. Versatility and overflowing imagination have led Benni to explore different modes, to contaminate them and bend them to his purposes, with both good and bad results.

Some critics and commentators have dismissed his writings as mere entertainment or mannerism; the majority however have regarded his works as committed political and social

Address correspondence to Monica Boria, Anglia Polytechnic University, East Road, Cambridge CBI IPT, UK 
satire and praised the originality of his comic verve. ${ }^{1}$ An exclusively literary approach could not provide a fair insight into Benni's literary and intellectual activity as a whole. The increasing influence of the mass media and of popular culture on traditional artistic fields such as literature, and the consequent blurring of 'high-brow' and 'low-brow' categories, require a widened critical perspective, which can complement the traditional tools offered by literary criticism. Working within the framework of cultural studies has proved useful in bringing together the various strands that run through Benni's work: his political commitment, his love for literature and his humour.

Politically, the roots of Benni's humour are to be found in the student spirit and political protest of the Movimento '77, among whose claims the re-appropriation of free time and the right not to work were central: "it was around consumption and leisure activities that the movement of the "young proletarians" developed its specific forms of action and established its collective identity. ${ }^{, 2}$ Civil disobedience was a crucial aspect of their protest, as was the use of irony and humour to mock authority. The slogans created by the movement made use of all sorts of materials, from advertising jingles to pop music. It was through encounters with left-wing intellectuals like Rossana Rossanda and young artists like cartoonist Andrea Pazienza that Benni moved close to the counter-cultural milieu of the Movimento ' 77 in Bologna. Contingent circumstances such as the sharp economic crisis (Benni himself had to face unemployment) and the liberalisation of the airwaves created the conditions (and the opportunities) for his involvement. He started as a co-founder, in Bologna, of a free radio station and the self-managed paper Il Foglio and then progressed towards more cutting-edge publications such as the satirical magazine Il Male (1978-I982) and the far-left weekly (later daily) Il Manifesto.

Benni's consistent and deliberate attempt to provoke since then has continued to make him a counter-cultural figure. His programmatic rebelliousness puts him easily into the critics' firing line and makes his work susceptible to charges of repetitiveness, oversimplification and formulaic moralizing. He is obviously aware of this danger and, in one of his recent public statements, has responded with the formula: 'meglio apocalittici che indifferenti'. It is difficult to establish to what extent his original political stance has been turned into a marketing strategy. Yet, on close reading, the subtle rhetorical strategies employed, as well as the strong political intention that underlies his work, belie the label of 'popular fiction writer' put on Benni by some critics. Benni's 'impegno', after going through phases of counter culture, retreat, crisis and finally new forms of commitment, has always been a characteristic aspect of his activity. Literary work has always been his form of cultural and political engagement, which he has carried out through collaborations with the left-leaning press (Il Manifesto, l'Espresso, Cuore, La Repubblica), declining more lucrative options. Together with various cultural organizations and single artists and intellectuals, Benni has worked on very diverse projects and events: a film, Musica per vecchi animali (with Dario Fo and Francesco Guccini, among others), which he wrote and directed; collaborations in international jazz festivals; courses throughout Italy on imagination and writing; seminars and talks, especially in Bologna, on topics like philosophy and politics, education and racial issues, medicine and the new technologies. The relationship with Bologna, where he has lived since the age of I6 and still spends most of his time with his young son, is one of love and hate: love of the city's cultural vivacity and grassroots socialist tradition, hatred of its moderate politics, which has led to recurrent conflicts with the local administration. He offers financial support to local charities committed to cultural or social initiatives and 
groups within the centri sociali; the royalties from his book Dottor Niù (200I) for instance, was devoted to some of these. In the postmodern lapse of faith in ideologies Benni's discourse retains a leftist counter-cultural attitude, which takes the shape of alternative cultural projects and social commitment and, in his writing, of scathing humour and linguistic creativity.

One of Benni's early achievements was the successful use of the comic in serious contexts, and the misunderstandings that result. An early example of his style is Blues della circonvallazione, a poem that plays with language (the play on the words 'blues/bus') and metaphors (the bus journey as a hallucinatory 'trip') to capture the 'blues mood' of the student protest in a Bologna where the police are mobilizing. Benni's mocking tone does not target the political establishment alone; literary tradition is parodied too. In Dormi, Liù (see below), one of the most common themes of poetry of all times (lost love and the suffering of the poet) is expressed in the form of a nursery rhyme and alludes, in its form, to structuralist methods of interpretation. Benni's best achievements in this allusive practice are his pieces à la manière de, where he parodies famous poets like Montale (Il Cielo) and Carducci (Le Vecchiette). It is these early works that form the main focus of this study.

When asked the reason why he writes, Benni's simple and pregnant answer has been: 'perché mi piace leggere.' ${ }^{3}$ It has been suggested that, together with his multifaceted humour, the major feature of his writing is its allusiveness: 'Benni refers freely and frequently to Joyce, Queneau, Beckett, Melville and Dante among others and on a range of scales. References can take the form of a casually-quoted line or phrase, or sustained parody, and he returns to the same material again and again, playing with it and reworking it in endless permutations. ${ }^{4}$ This practice was the actual starting point of Benni's attempts to write. The isolation of countryside life in Emilia Romagna, where he grew up, favoured his creativity. He enjoyed reading but also writing. He liked imagining different endings to famous stories and novels; he wrote, for instance, fifteen different ones for Moby Dick, one of which saw Captain Ahab's crucial encounter with the whale being spoilt by the unexpected arrival of his wife, very cross with him for being away from home for so long.

Benni's humorous and ironic mode seems to date back to these very first efforts, which would find new impetus in the stuffy seriousness of the Italian school system of the early I960s. In a newspaper interview in the early I990s Benni recalled his years at the liceo thus:

Il fatto che fossi un lettore di autori inglesi veniva considerato un'imperdonabile stravaganza: 'Ma come, non hai letto il Pindemonte e ti permetti di leggere Steinbeck?' C'era sempre da qualche parte la figura del Carducci che si stagliava possente o l'anima del Leopardi che appariva dolente. Quando in classe leggevamo Gozzano e ci permettevamo qualche sorriso, perché Gozzano è divertente, il professore ci fulminava dall'alto della cattedra: 'Allora? Ridiamo?' Insomma il ridere visto come cosa immorale. Il momento in cui finii il liceo, avevo già deciso: 'Sarò comico!'

The atmosphere in the education sector mirrors the outlook of mainstream Italian literary establishment of the time, and to a certain extent, of today. The rich comic strand that runs through Italian literature has generally been sidelined by Italian criticism. Studies of the multifaceted nature of the comic in Italian literature are very few. Some of them were prompted, in the I970s, by the impact of Bakhtin's work; the most comprehensive ones usually deal with the literary canon and the scope of the investigation typically stops in the I980s. ${ }^{6}$ The scarcity of scholarly research in this field to this day is only partly explained by the major influence on Italian intellectuals of Benedetto Croce's aesthetics. A more crucial 
factor is probably represented by what Mazzacurati has termed 'la malattia adolescenziale d'ogni nazione giovane, che accende la febbre dei Grandi Fini e dei Grandi Valori', which allows little space for the comic. ${ }^{7}$ Furthermore, Italian society appears to be irredeemably prone to passions and to performing them, somehow oblivious to the elegance of irony and the earnest moral stance of humour. Mazzacurati concludes, rather dismally, that 'sulla questione dell'umorismo, dopo Pirandello, nessuna estetica o poetica post-crociana si è particolarmente distinta da noi, se non per disinteresse e sordità' (ibid.). In the specific field of satire in Italian literature, for example, the first major critical work to cover a substantial time span (five hundred years) was published only in $1987 .{ }^{\circ}$ Maybe this neglect should not surprise; after all, unlike English literature for instance, Italy cannot really boast a strong tradition in this field. When we turn to the twentieth century, the difficulties posed by censorship (during the Fascist era and beyond) appear as only one of the reasons that have affected this kind of expression: 'La derisione dei potenti è stata quasi sempre giudicata un'offesa alle istituzioni piuttosto che un salutare antidoto contro gli arbitri di chi governa. [...] Basti ricordare che si sono mantenuti fino ad oggi nel nostro codice i cosiddetti reati d'opinione, tra i quali spicca il famigerato istituto del vilipendio.' ${ }^{9}$ It is true, however, that periods of heated political debate and institutional changes have been more conducive to satire, especially political satire, as was the case in the late I960s and the I970s.

Benni's early writings range from press columns to ballads, mock nursery rhymes and pastiche; they blend a satirical purpose with a programmatic fight against the codification and inflexibility of highbrow culture and style. Sometimes his methods are plain and straightforward and his efforts just experiments or divertissements - humorous literary elaborations on a theme. They always, however, rely on an imaginative and unusual use of the language. As mentioned earlier, it is in the student spirit and political protest of the Movimento ' 77 that the roots of their humour are to be found. In contrast to previous counterculture movements, the Movimento ' 77 was particularly keen to explore issues related to language, creativity and the mass media (radio in particular, after the liberalization of the airwaves in 1975). Umberto Eco at the time regarded the linguistic manipulation of what he termed 'i nuovi barbari' as the latest chapter in the history of the avant-garde movements. ${ }^{10}$ Maurizio Calvesi, too, thought that a new avant-garde had been born, 'una avanguardia di massa', which linked this protest to a widespread urge of artistic expression among the lower classes. ${ }^{11}$ Caludia Salaris allows us to trace the sources of the subversive practice of their humour in various movements: futurism, surrealism, situationism, dada, body art. ${ }^{12}$ The favourite devices employed by the Movimento ' 77 were punning and anti-slogans, nonsense, détournement, but above all pastiche and parody. Leaflets, news-sheets or posters would have titles like Felce e Mirtillo, (echoing the communist symbols of falce and martello), Godere Operaio (a smirking allusion to the extra-parliamentary group Potere Operaio) or L'Unanimità (a reference to the Communist party daily L'Unità). Among the materials used and revisited by the Movimento were limericks, nursery rhymes, and children's comics. Modelled on the popular illustrated stories of Il Signor Bonaventura by Sergio Tofano, Stefano Tamburini produced strips of the following kind:

Sesso, corpo, personale,

Nella lotta al capitale,

Fanno parte non scordiamo,

Della vita che vogliamo. 
Dalle fabbriche ai quartieri

Non c'è posto pei pompieri,

Un sol grido proletario:

PIÙ SALARIO, MENO ORARIO (Salaris, p. 60)

In the piece entitled 'Per una vacanza d'evasione da San Vittore all'Ucciardone', published in the foglio called Cospir/azione (Summer 1977), the issue of leisure time, demanded by the 'Indians' as a right for everybody, is combined with the issue of the repressive tendencies of the state towards the Movimento:

Grazie alla benevolenza di un ministro di polizia, quale da molti anni (40?) non si ricordava, il problema delle vacanze, assillo periodico della nostra gioventù, è stato, per una parte consistente di giovani (non si conosce ancora la cifra ufficiale) felicemente risolto. Non più spiagge affollate e prezzi proibitivi, ma lunghe e riposanti giornate al 'fresco' dei nostri rinomati 'bagni' penali. La gamma a disposizione è veramente varia: si va dal castello medievale, all'antico e austero convento francescano [...] lunghi periodi di vero isolamento in apposite celle serviranno a restiruire il naturale equilibrio ai troppo esuberanti $[\ldots]^{13}$

The aim was to ridicule authority and the political establishment (especially of the left), but most of all to reclaim a playful dimension, an alternative standpoint that was often misunderstood. As Nanni Balestrini pointed out:

La cultura nazionale, che già non aveva mai avuto una vocazione per l'ironia, manifestava una completa mancanza di spirito. La tendenza [...] a prendere grevemente tutto alla lettera domina sia la cultura cattolica che quella comunista. Il movimento ribaltò del tutto la situazione: si proclamò una realtà delirante [...] ogni luogo di enunciazione proiettava il proprio mondo immaginario attribuendogli una realtà soltanto comunicativa. Il potere rispose interpretando quegli immaginari come cospirazione. ${ }^{14}$

Benni's Blues della circonvallazione is an example of the spirit of those years. It refers to the state of alert in Bologna during the student mobilization.

A san Donato mi son rovinato ed ero già in para a porta Galliera ma un tizio coi baffi / giù a porta Saffi mi ha detto, amico, va tutto benone è solo il blues della circonvallazione.

A porta Zamboni autoblindo e gipponi

a porta Mazzini parà e celerini diobono, sto male anche in San Vitale ed in Mascarella / una sbarbatella mi fa, su con la vita, coglione è solo il blues della circonvallazione.

E a Porta Lame sono solo come un cane e in San Felice son tanto infelice e in Sant'Isaia c'è la polizia che urla al megafono / nessuna impressione è solo il blues della circonvallazione.

Ed in Saragozza mi son fatto di pizza a Porta D'Azeglio non sto niente meglio 
ed in Castiglione, che gran depressione non ho una lira / neanche un gettone soltanto il blues della circonvallazione.

Ed in Santo Stefano c'è una bus-fermata seduta a aspettare una mezza strippata mi dice amico, sali con me facciamo un giro con il trentatré ad ogni porta / ci facciamo un cannone è questo il blues della circonvallazione.

Ma al Barracano sale un pulismano e dice 'siete in contravvenzione per blues abusivo della circonvallazione' mi prende da parte, 'ho della roba da darti se proprio vuoi farti, ho dei dischi di Sarti' e siccome al business non faccio attenzione mi carica su e mi porta in prigione per quale ragione? / non c'è una ragione è solo il blues della circonvallazione. ${ }^{15}$

The unconventional and humorous tone is established from the very title by juxtaposition of the words 'blues', evocative of deep black voices and melancholic stories of far away places, with 'circonvallazione', the mundane, everyday route of the local bus route. The title also expresses the paradigms that modulate the entire composition, playing on three main ideas: the blues mood, a bus journey and a drug experience. These are generated by the play on words 'blues/bus' and the metaphor of the journey as a 'trip'. The binomial 'blues/bus' provides the major undercurrent of the poem. The idea of oppression and human injustice that the word 'blues' immediately conjures up is linked to the measures taken against the practice of autoriduzione of transport fares that the young proletarians of the Movimento advocated. 'Blues' also refers to the downbeat mood caused by the drug use that was becoming widespread in those years among many young people. The text can thus be read as a blues ('an autobiographical chronicle of personal catastrophe expressed lyrically' as Ralph Ellis has put it), ${ }^{16}$ a bus journey round Bologna in the years of the student protest and the hallucinatory experience of a drug-addict.

The poem presents many features of the blues form. According to the definition given by Ellis, 'the blues is an impulse to keep the painful detail and episodes of a brutal existence alive in one's aching consciousness, to finger its jazzed grain, and to transcend it, not by the consolation of philosophy but squeezing it from a near-tragic, near-comic lyricism' (ibid.). In Benni's poem, the basic mood of the blues can be found as well as a strong rhythm that makes it suitable for music; the metre too is in line with the traditional four beats of popular and oral poetry. The structure deviates from the traditional blues form; the canon, set by 'the father of the blues', W. C. Handy, consists of three lines of four beats each (the first line repeated twice) followed by a third end-rhymed line. This poem instead has six stanzas of five and six lines (except for the last one, which has nine lines) and repetition and end-rhyme features are only vaguely reproduced by the couplet at the end of each stanza, where the last line is repeated almost identically throughout the poem. Two different rhyming schemes can be highlighted in the poem: the end-rhyme pattern in the fifth stanza (AABBCC) and internal rhymes in the first four stanzas (plus the above mentioned recurrent couplet). These two schemes are blended in the last stanza, which, taking up the 
formal features as well as the themes introduced previously, provides a comprehensive conclusion for the poem.

Benni uses everyday language as well as the jargon of the drug world ('para', 'strippata', 'ci facciamo un giro', 'cannone', 'roba'). Colloquialisms and informal interjections ('diobono', 'coglione') are also interspersed throughout. It is interesting to note the anglicisms in the fifth stanza: 'strippata' (from 'strippare' which derives from the English 'trip') to refer to a drug-addict, 'pulismano', an ironic calque of 'policeman', and the unusual 'bus-fermata' that ironically echoes the title and its claim to foreign charm. Similarly, the whole idea of the poem, resting on the ambiguity of 'trip', can be regarded as mocking the attitude of a rebellious youth influenced by the myth of the American 'beat generation'. This is achieved by echoing the Bob Dylan song, Mr Tambourine Man, which is itself a description of hallucinatory states in the form of an invocation to the pusher, the 'Tambourine Man' of the title. ${ }^{17}$

Given this irony and the general tone of the piece, is then Dylan, this icon of American counterculture, also being ridiculed, at least indirectly? Linda Hutcheon suggests that the widespread use of allusion in contemporary art and its wide range of intent, from respectful admiration to scornful mockery, can be regarded as a form of 'imitation characterized by ironic inversion, not always at the expense of the parodied text'; she thus defines modern parody as 'repetition with critical distance, which marks difference rather than similarity'. ${ }^{18}$ In these terms, Dylan's song is used as a blueprint for the poem (as is the blues form) and can be seen as a tribute to Dylan's art. Benni's ambiguous attitude of admiration for and suspicion of American culture is more explicit in other works of these years and is part of that same general cultural and political attitude of left-wing artists and intellectuals of this period. ${ }^{19}$ It can be found, for instance, in the songs of popular cantautori like Francesco De Gregori, Pierangelo Bertoli and Lucio Dalla. The Bolognese Francesco Guccini, in his song Piccola Città (I972), talks about a 'vuoto mito americano/di terza mano', and in the song about an unlucky hitch-hiker, Statale 17 (I967), he ironically alludes to the influence that Kerouac's cult novel On the Road had on his generation. ${ }^{20}$

In Blues della circonvallazione, the almost obsessive reference to Bologna (by the naming of districts) is not only a device to build up the rhythm and to signpost the stops of the 'circonvallazione'. It can also be read as an explicit reference to the events leading to the big rally which took place in Bologna at that time after the killing of the student Lo Russo by a policeman. The mocking of the police as the embodiment of established authority here takes the form of exaggeration and non-sense; deliberately exaggerated is the description of their power ('autoblindo e gipponi', 'parà e celerini', 'urla al megafono') and non-sensical is the scrambling of semantic markers ('siete in contravvenzione per blues abusivo della circonvallazione'). The jargon of bureaucracy is implicitly ridiculed in this line, but the attack is carried further with the implied charge of corruption in the line "mi prende da parte, "ho della roba da darti/se proprio vuoi farti"”. Similar hints can be found in Benni's 'Visita guidata alle bellezze di Roma' where a group of tourists are shown around the capital while the police forces are mobilizing. ${ }^{21}$

Leaving for a moment the specific geographical and historical context, the generally urban setting of the poem stands out. It is part of a section of the work entitled 'Blues urbani', which voices Benni's concern for the alienation of urban existence, especially as experienced by the young and the old of the lower classes. This theme is recurrent in his 
later work, the novels in particular. ${ }^{22}$ His stories have been referred to as a 'post-modern enquiry into metropolitan life'. ${ }^{23}$ Set against a backdrop of imaginary worlds and fantasy Benni's novels in fact represent everyday tragicomic events and the grotesque degradation of modern life. This concern as well as his typically imaginative use of language can be seen in the passage from his second novel, La compagnia dei Celestini. ${ }^{24}$ It is a description of the seaside resort 'Rigolone Marina, perla del mare Adrenalio', the all too familiar place on the Adriatic, where discotheques cater for any taste:

[...] dai rappers ai mazurkofili, dai revivalisti ai post-moderni, dai bevitori di birra ai consumatori di extasi, dai rocchettari ai paninari ai casinari ai metallari ai pataccari ai piadinari ai dark-soft agli heavy-metal ai grunge-sound ai pooh-vraz agli one-hit-wonders ai glam-gay agli evergreeen ai naziskin ai funkadelics agli ice-fuckers ai dambda-bevar ai tamla-motown. (ibid., p. I23)

It is easy to recognize the post-modern tendency to taxonomize in this passage. Lists of items in Benni serve as the embodiment of categories of the spirit. The humour is achieved through the unexpected juxtaposition of ordinary and imaginary elements; here Benni's linguistic pastiche draws on Italian, English and the Emilia-Romagna accent: 'pooh-vraz' is poveracci (where the spelling is an allusion to the Italian pop group The Pooh); 'dambdabevar' is dammi da bere with a samba flair; and 'tamla-motown' is dammi la moto, but also the name of a well-known type of American music.

In Benni's view language has to be creatively reassembled to reflect the complexity of contemporary multicultural society and to free our discourse from the impoverished language of the mass media. Imagination is the keyword for Benni and the result is a blend of foreign words, Italian dialects, classical languages, the language of rock and roll, and the language of the comics. This is what triggers amusement and activates the political purpose; the choice of music and of Emilia Romagna is not accidental; as Maria Corti reminds us, Italian rock was born in Bologna where it became one of the forms of expression of the ala creativa of the movement of $1977 .{ }^{25}$ Maybe Benni is hinting here at the song Mamma dammi la benza by the Bolognese rock group GazNevada, which played the song during the notorious meeting of the Movimento in September I977. The purpose of Benni's reference seems to be to attack a widespread superficiality and lack of commitment among the younger generation.

Among the materials revisited by the Movimento were forms of popular poetry and fumetti. The next poem in Prima o poi l'amore arriva, 'Dormi, Liù', draws on the same practice; it revolves around the loss of a woman and displays a contamination of popular culture (the song by Bixio, Parlami d'amore Mariù) with high culture (Wedekind's Lulu). The subject matter is probably the most common theme of poetry of all times, as the subtitle claims ('frammento classico di Eparione di Corinto'). 'Classico', with its ambivalent meaning due to collocation after the noun, can probably be taken as standing for 'typical', 'recurrent', rather than 'by a classical author'.

Dormi, Liù

(frammento classico di Eparione di Corinto)

Dorme la corriera

dorme la farfalla

dormono le mucche

nella stalla 
il cane nel canile

il bimbo nel bimbile

il fuco nel fucile

e nella notte nera

dorme la pula

dentro la pantera

dormono i rappresentanti

nei motel dell'Esso

dormono negli Hilton

i cantanti di successo

dorme il barbone

dentro il vagone

dorme il contino

nel baldacchino

dorme a Betlemme

Gesù bambino

un po' di paglia come cuscino

dorme Pilato

tutto agitato

dorme il bufalo

nella savana

e dorme il verme

nella banana

dorme il rondone

nel campanile

russa la seppia

sull'arenile

dorme il maiale

all'Hotel Nazionale

e sull'amaca

sta la lumaca

addormentata

dorme la mamma

dorme il figlio

dorme la lepre

dorme il coniglio

e sotto i camion

nelle autostazioni

dormono stretti

i copertoni

dormono i monti

dormono i mari

dorme quel porco

di Scandellari

che m'ha rubato

la mia Liù

per cui io solo

porcamadonna

non dormo più ${ }^{26}$

In Benni's view, humour is an innate quality that requires a purpose and almost scientific precision in order to be effective. The poem seems to provide a clear example of this. It 
takes the shape of a lullaby, or rather a mock bed-time song to send Liù to sleep, that is to silence the memory of the person haunting the lyrical 'I' and keeping it awake. The composition results from the transformation of the matrix 'everyone is asleep but me' through the model of a reiteration (implicit in lines 5-7) of the verb 'to sleep'. ${ }^{27}$ The expansion of the matrix, thus the generation of the text and its significance, is carried out in two ways: first, the matrix is applied to semantic fields that do not pertain to the verb 'to sleep' ('dorme la corriera', 'dormono stretti / i copertoni', 'dormono i monti / dormono i mari'); second, it is exaggerated in contexts where it would otherwise be legitimate ('russa la seppia'). The expansion takes thus the form of a repeated metaphor that pervades everything and therefore enhances the original idea of a world asleep where only the poet is hopelessly and helplessly awake. This is achieved by gradually increasing the emphasis of the statements and the rhythm ('dormono i monti / dormono i mari' being the climax), and this makes the revealing conclusion stand out.

The other aspect that contributes to the significance of the poem is the conversion of the orientation of the matrix by means of humorous lexical interferences which affect the sombre connotations of the typical symbolism of traditional nursery rhymes. In contrast with the usual representations of pleasant near-pastoral scenes ('la farfalla', 'le mucche / nella stalla', 'il cane', 'la lepre', 'il coniglio') or religious values ('dorme a Betlemme ...', 'la mamma', 'il figlio'), we find expressions that mock this idyll (the neologism 'bimbile') or point to a more down to earth and corrupted world: 'dorme il maiale ...', 'e nella notte near ...', where 'pula' is the streetwise jargon for 'polizia'. This is added to by the juxtaposition of the extremes (the rich and the poor) and finally the swearword ('porcamadonna') which makes up the penultimate line. The humorous effect of this conversion does not affect the genuine stance of the poem, which seems in fact to gain in strength thereby. If the satirical tone is also an expression of anger, the choice of this mode seems appropriate to the poet's feelings. In fact, the position and outrageousness of the curse in the poem make it sound like a cry of pain.

Sheer satirical impact is more evident in other pieces composed around the same period, such as Piove, modelled on D'Annunzio's La pioggia nel pineto:

Piove

(D'Annunzio-Modugno-Mogol)

Dal $52^{\circ}$ Festival della canzone italiana

Ascolta

Non odo

Parole che dici

Umane

Ma odo

Parole non nuove

Che dicono

Gocciole e foglie

E agenzie di stampa

Democristiane

Piove

Sui nostri volti silvani

Sui servizi segreti

Americani

E l'acqua arriva

A metà Fanfani 
Piove

I fiumi escon fuori

Escono gli evasori

I ladri i truffatori

Piove

Sui fiancheggiatori

Su paesi e città

Piove sulla Carrà

Sull'Italia che frana

Piove in val Padana

Piove sui tamerici

Su Bisaglia e i suoi amici

Piove su Gava

Così almeno si lava

$[\ldots]^{28}$

In successive years, in line with these first attacks on the literary tradition, Benni produces some very successful pieces à la manière de, which provide an example of how parody worked as a counter-cultural practice for the Movimento. The international poetry festival organized by the Rome City Councillor Renato Nicolini in I979, in which a number of acclaimed poets took part, offered Benni an opportunity to mock 'l'estate romana'. He provided 'translations' of poems by Ginsberg and Yevtushenko, which were taken as authentic by some. The newspaper Il Messaggero in its review even suggested the date and the place of composition of Benni's pastiche of Yevtushenko, and the critic Antonello Trombadori, in a TV talk show, presented the 'pseudo-Ginsberg' as an instance of the senselessness of contemporary poetry. ${ }^{29}$

Benni's pieces à la manière de, composed in those years and later collected in Prima o poi l'amore arriva (I98I) and Ballate (I99I), are indeed effective. ${ }^{30}$ In the following example, many typical features of Montale's poetry are well reproduced: the incipit in medias res, the sharp sounds of the words, the eloquent style, the sullen tone:

Il cielo

(una poesia inedita di Eugenio Montale)

Il cielo, mi dite: ma cos'è il cielo?

Forse la tenda azzurra che sovrasta

Pattume di sogni e di idee frattaglia

Dove zirla il tordo e l'aereo fracassa

Dove nuvole s'acciaccano in battaglia

E satelliti s'imbrancano e fan schiera

Come zinzelle d'intorno alla lumiera?

Marziani, mi dite: ma cosa me ne importa?

Quale in estate di Rapallo africosa

Raccoglie il mar da terra paccottiglie

Cocomeri, hatù, carte e bottiglie

E porta alla deriva verso il largo

Ogni merdaglia di condominio e albergo

Tale la terra, stronzo solitario

Galleggia tra le stelle in gran mar d'aria

Un ufo, dite, un ufo? ma io sono stufo.

Guardo la redola nel fosso, in su la nera 
Corrente sorvolata di libellule

E mentre l'allarme antiaereo suona

M'addormento in poltrona ${ }^{31}$

Parody and pastiche have always given rise to heated debate. In recent times some scholars have emphasized the positive aspects of their use (e.g. Hutcheon above); others have been more sceptical about their validity. According to Fredric Jameson, for instance, both parody and pastiche involve 'the imitation or, better still, the mimicry of other styles and particularly of the mannerisms and stylistic twitches of other styles'. ${ }^{32}$ But for Jameson, whereas parody results in a mockery of the originals, with the effect of casting ridicule on the eccentric nature of these peculiar styles, pastiche is 'blank parody, parody that has lost its sense of humour [and] the satirical impulse' (ibid.). This view sees the widespread use of pastiche in today's writers as a symptom of an aesthetic impasse: they do not seem to be able to create something different and new because what they perceive as really innovative is already there. For this reason all that is left to them is imitation of existing styles. On the Italian front, Gorni justifies parody 'come compenso alla sacralità e all'immutabilità del testo scritto, che la filologia testuale e contemporanea ha esaltato e imposto'. ${ }^{33}$ The critic quotes Montale's last poems as a supreme example of this contemporary trend but does not hide a certain disappointment: 'quasi un presagio delle nuove fortune di parodia e autoparodia sul finire di questo secondo millennio’ (ibid.). Barberi Squarotti highlights a belief in political and moral protest as well as a rehabilitation of poetry as rhythm, sound and verbal techniques as being represented by this parodic tendency: ' a patto che l'ironia ponga in rilievo che non l'esempio antico o elevato è abbassato ma che il contesto nuovo e attuale è degradato.' 34

Benni's attempts seem worthy of inclusion among the positive uses of parody and pastiche. In Il cielo, Benni is paying tribute to Montale's poetry and, at the same time, he is mocking his poetic development from that poet's first collection, Ossi di seppia, to a much later one, Satura, where disharmony with the world, bitterly expressed, gives way to a more quotidian setting and simpler language, reflecting the poet's disorientation in the world and his retreat into the private. Beyond the discourse on Montale (admiration/disappointment), Benni's own disharmonic relationship with the world is voiced; words like 'merdaglia' and 'stronzo solitario' are just the tip of the iceberg of the ecological disaster that is portrayed in the stanza in which they appear. This theme recurs in other poems, in his novels and in the more recent columns for La Repubblica. ${ }^{35}$ Benni's ecologism is an example of the consistency of his commitment, but when it comes to the effectiveness of his comic strategies, the sparkling humour of the early years appears tarnished by a gloomier vision and maniera.

Some of the themes covered in the press columns and the amused irreverence of the 'exercises in style' described above return in the narratives, which often overflow with linguistic creativity and irresistible verve, as for example the novels Terra! (I983) and La compagnia dei Celestini (1992). It is, however, true that, more recently, Benni's fiction has appeared gradually less convincing. His novels Elianto (1996), Spiriti (2000) and Saltatempo (200I), for instance, strongly conform to the structure and themes of the previous ones, and show a diminution in linguistic creativity, satirical bite and overall originality.

Yet Benni's literary career seems to have taken a new turn. His texts have often been adapted for the stage by professionals and amateurs alike: because of their topicality, the 
bittersweet humour and the surreal and fantastic elements, they seem to provide very suitable material for theatre scripts. His comic talent has led Benni to successful co-operations with well-known left-wing stand-up comedians and actors, such as Dario Fo, Beppe Grillo, Paolo Rossi, Alessandro Bergonzoni, the Broncowitz, Angela Finocchiaro and others. This activity has resulted in various 'atti unici' and plays, some of which have been collected by Feltrinelli publishers in Teatro (1999) and Teatro II (2003). Writing for the theatre has made Benni more aware of his tools as an author, with beneficial consequences: 'Mi sono accorto di essere verboso e ho dovuto correggere molti errori; in questo [il regista] Gallione mi ha aiutato molto. Il rapporto tra scrittura e teatro è di lontananza e unione, azioni sceniche e parole: ho dovuto imparare a rarefare, a tagliare, a scrivere al femminile, specie per i monologhi. ${ }^{36}$ His play, Amlieto. Il principe non si sposa, written in 1996 for the theatre company Il Teatro dell'Archivolto, provides a fine example of political satire and postmodern pastiche. ${ }^{37}$ Together with the theatre, the regular columns for La Repubblica, collected as Dottor Niù. Corsivi diabolici per tragedie evitabili (see note 35), have marked Benni's return to a symbolically public cultural arena as well as to his most congenial form: the short satirical piece.

${ }^{1}$ See, for example, Stefano Tani, Il romanzo di ritorno. Dal romanzo medio degli anni sessanta alla giovane narrativa degli anni ottanta (Milan: Mursia, I990), pp. 216-23; Filippo La Porta, La nuova narrativa italiana. Travestimenti e stili di fine secolo (Turin: Bollati Boringhieri, I995), pp. I83-87; Marino Sinibaldi, Pulp. La letteratura nell'era della simultaneità (Rome: Donzelli, I997), pp. 27-34; Remo Ceserani, 'Modernity and postmodernity: a cultural change seen from the Italian perspective', Italica, 7I (1994), 369-84; Cristina Degli Esposti, 'Interview with Stefano Benni: a post-modern moraliste', Italian Quarterly, 32 (I995), 99-I05; Rocco Capozzi, 'Apocalittici e integrati nell'industria culturale postmoderna', in Scrittori, tendenze letterarie e conflitto delle poetiche in Italia (1960-1990), ed. by Rocco Capozzi and Massimo Ciavolella (Ravenna: Longo, I993), pp. 205-22.

${ }^{2}$ Robert Lumley, States of Emergency. Cultures of Revolt in Italy from 1968 to 1978 (London: Verso, I990), p. 3 OI.

${ }^{3}$ Ferdinando Camon (ed.), Perché scrivete? Rispondono 109 scrittori italiani (Nord Est: Padua, I989), p. I6.

${ }^{4}$ Carol O'Sullivan, 'Intercomically Textual: Stefano Benni's "esercizi di stile"' (unpublished paper presented at postgraduate colloquium 'Senses of Humour', Cambridge, i 8 March 2000).

${ }^{5}$ Stefano Malatesta, 'Cari comici siete a pezzi', La Repubblica, I4 October I992, 27.

${ }^{6}$ Some of the major works are: Giulio Ferroni, Il comico nelle teorie contemporanee (Rome: Bulzoni, I974); Giorgio Barberi Squarotti (ed.), Lo specchio che deforma. Le immagini della parodia (Turin: Tirrenia Stampatori, I987); Nino Borsellino, La tradizione del comico. L'eros l'osceno la beffa nella letteratura italiana da Dante a Belli (Milan: Garzanti, I989).

${ }^{7}$ Giancarlo Mazzacurati (ed.), Effetto Sterne. La narrazione umoristica in Italia da Foscolo a Pirandello (Pisa: Nistri-Lischi, I990), p. 9.

${ }^{8}$ The text referred to here is I bersagli della satira, ed. by Giorgio Barberi Squarotti (Turin: Tirrenia Stampatori, I987), a collection of essays on satire from Leon Battista Alberti to Italo Calvino and Sebastiano Vassalli. The prestigious Einaudi series, Letteratura Italiana (I986), edited by Alberto Asor Rosa, devotes a section to the comic and to parody, leaving out satire altogether.

${ }^{9}$ Giulio Carnazzi, La satira politica nell'Italia del Novecento (Milan: Principato, I975), p. I. The offence of public defamation is currently under review further to a new bill that has been proposed.

${ }^{10}$ Umberto Eco, Sette anni di desiderio (Milan: Bompiani, I983).

${ }^{11}$ Maurizio Calvesi, Avanguardia di massa (Milan: Feltrinelli, I978).

${ }^{12}$ Claudia Salaris, Il movimento del settantasette. Linguaggi e scritture dell'ala creativa (Bertiolo: AAA Edizioni, I997).

${ }^{13}$ In Pablo Eucharren, Parole Ribelli. I fogli del movimento del '77 (Rome: Stampa Alternativa, I997), p. 95.

${ }^{14}$ In L'orda d'oro, ed. by Primo Moroni and Nanni Balestrini (Milan: SugarCo, I988), p. 360.

${ }^{15}$ In Stefano Benni, Prima o poi l'amore arriva (Milan: Feltrinelli, I98 I [I994]), p. 29. First published in Stefano Benni, Il Benni furioso (Rome: Il Manifesto, I979), p. I8. 
${ }^{16}$ Quoted in The Norton Anthology of African American Literature, ed. by Henry Louis Gates and Nelly Y. McKay (New York and London: Norton, I997). Quotations are from pp. 22-23.

${ }^{17}$ Here are some of the lyrics of the song, first released in 1965 : 'Take me on a trip upon your magic swirling ship / my senses have been stripped / my hands can't feel to grip / my toes too numb to step / wait only for my boot heels to be wandering. / I'm ready to go anywhere, I'm ready for to fade / into my own parade / [...] Take me disappearing through the smoke rings of my mind / down the foggy ruins of time / [...] far from the twisted reach of crazy sorrow. / [...] Let me forget about today until tomorrow.' ${ }^{18}$ Linda Hutcheon, A Theory of Parody. The Teachings of Twentieth-Century Art Forms (London and New York: Methuen, I985), p. 6.

${ }^{19}$ See, for example, the poem 'A Torre' in Prima o poi l'amore arriva, p. I28: 'mi scrivi a Bologna / che anche in America / esiste l'insonnia / ma è un'altra cosa / restare sveglio fino alle sei / a sentire una radio / che dice allright okey'; and his article 'I love New York', in the published collection of Benni articles from Il Manifesto (Spettacoloso [Milan: Mondadori, I98I], p. I6I).

${ }^{20}$ In his Album concerto (I979), when presenting this song, Guccini’s irony sounds very close to Benni's: 'era molto bello [Kerouac's book] letto in italiano, però con i nomi americani. Dice "quella sera partimmo John, Dean e io sulla vecchia Pontiac del ' 55 del babbo di Dean e facemmo tutta una tirata da Omaha a Tucson". E poi lo traduci in italiano e in italiano dici "quella sera partimmo sulla vecchia Millecento del babbo di Giuseppe e facemmo tutta una tirata da Piumazzo a Sant'Anna Pelago”... Non è la stessa cosa, gli americani ci fregano con la lingua.'

${ }^{21}$ Stefano Benni, La tribù di Moroseduto (Milan: Mondadori, I977), pp. I4I-43.

${ }^{22}$ See also the section 'Blues metropolitani' in Ballate, pp. I07-22, the novel Comici spaventati guerrieri (Milan: Feltrinelli, I986), and Blues in sedici. Ballata della città dolente (Milan: Feltrinelli, I998).

${ }^{23}$ Cristina Degli Esposti, 'Interview with Stefano Benni', p. 99.

${ }^{24}$ Stefano Benni, La compagnia dei Celestini (Milan: Feltrinelli, I992 [I996]), p. I23.

${ }^{25}$ Maria Corti, 'Parola di rock', in Parole in musica. Lingua e poesia nella canzone d'autore italiana, ed. by Lorenzo Coveri (Novara: Interlinea, I996), pp. 45-53 (first published in Alfabeta, 34 [I982], 3-4).

${ }^{26}$ In Prima o poi l'amore arriva, p. 64.

${ }^{27}$ Michael Riffaterre, Semiotics of Poetry (Bloomington and London: Indiana University Press, I978), p. I9, describes the matrix as a 'minimal and literal sentence' that is 'hypothetical, being only the grammatical and lexical actualization of a structure'. He goes on: 'It is always actualized in successive variants; the form of these variants is governed by the first or primary actualization, the model. Matrix, model and text are variants of the same structure.'

${ }^{28}$ Stefano Benni, Non siamo stato noi (Rome: Savelli, I979), p. I40. It may be worth adding that D'Annunzio's poem (early I900) had already been used in a similar way by Montale ('Piove', in Satura [Milan: Mondadori, I97I]), so adding a further layer to the parody. Benni's poem can be found in full at: http://web.infinito.it/utenti/t/tecalibri/B/BENNI_stato.htm.

${ }^{29}$ See note to 'Sutra di Nicolini (una poesia inedita di Allen Ginsberg)' and 'Castelporziano (una poesia inedita di Evghenij Evtušenko)', in Prima o poi l'amore arriva, pp. 84-88.

${ }^{30}$ Several critics express a similar view: Remo Ceserani, Raccontare il postmoderno (Turin: Bollati Boringhieri, I997), p. 208; Filippo La Porta, 'Gli ultimi vent'anni. Nuovi romanzi per nuovi lettori', in Manuale di letteratura. Storia per generi e problemi, ed. by Franco Brioschi e Costanzo Di Girolamo, IV (Turin: Bollati Boringhieri, I996), pp. 6I6-34 (p. 627). The pieces parody the style and themes of famous artists like Giovanni Pascoli, Allen Ginsberg, Paolo Conte and others.

${ }^{31}$ In Prima o poi l'amore arriva, p. 8I.

${ }^{32}$ Fredric Jameson, 'Postmodernism and consumer society', in Modernism/Postmodernism, ed. by Peter Brooker (London and New York: Longman, I992), pp. I63-79 (pp. I66-67).

${ }^{33}$ Guglielmo Gorni and Silvia Longhi, 'La parodia', in Letteratura italiana, ed. by Alberto Asor Rosa, V (Turin: Einaudi, I986), pp. 459-87 (485 and 487).

${ }^{34}$ Giorgio Barberi Squarotti, 'Il grande stile, l'apocalissi, l'ironia', in La parola ritrovata. La poesia contemporanea fra lingua e dialetto, ed. by Elio Cipriani, Andrea Foschi, Giovanni Nadiani (Ravenna: Longo, I990), pp. $17-28$ (p. 22).

${ }^{35}$ See, for example, 'La vispa Teresa', in Ballate (Milan: Feltrinelli, I99I), p. 38; the description of the polluted seaside resort 'Rigolone Marina', in La compagnia dei Celestini, p. I23; and 'Diario delle vacanze', in Dottor Niù. Corsivi diabolici per tragedie inevitabili (Milan: Feltrinelli, 200I), pp. 98-I02.

${ }^{36}$ Giovanni Mari 'Uno scrittore sul palcoscenico', Il Manifesto, I3 May I999, p. 26.

${ }^{37}$ From this play, broadcast on Rai 2 in 1998 , only a few songs have been published (Teatro II Milan: Feltrinelli, 2003). 